HISTORIA $67,2018 / 3,346-365$

DOI 10.25162/HISTORIA-2018-0013

MICHAEL STUART WILLIAMS

\title{
No Arians in Milan? Ambrose on the Basilica Crisis of $385 / 6^{*}$
}

\begin{abstract}
Modern explanations of the "basilica crisis" of 385/6 in Milan frequently suppose that the city's Christian population was divided into coherent, rival doctrinal factions. Yet Ambrose's own contemporary account assigns little or no role in events to any "Arian" faction among the people of Milan, and may indeed be read as denying the existence of such a community. Ambrose instead associates his opposition with the imperial court and portrays the dispute as between church and state. We need not take his word for it, but his evidence does little to establish this episode as a showpiece of open doctrinal conflict.
\end{abstract}

Keywords: Ambrose - Arians - Auxentius - Rhetoric - Heresy

\section{An “Arian” Faction in Milan?}

This article concerns "Arians", as that term was used in the heresiological polemic of the late fourth century $\mathrm{AD}$. It is therefore not intended to designate, as in its strict sense, only followers of the person and/or doctrinal position of the Alexandrian presbyter Arius. Nor is it meant to designate those Christians of the time whose preferred doctrinal formula defined the Father and Son not as consubstantial but merely as "alike" (homoios, similis): the term "homoians", used by many modern scholars as a more accurate label for these Christians than the polemical term "Arians", has its own problems, not least of which is its claim to identify the beliefs of large numbers of people whose views are often known only through the accusations of their enemies. ${ }^{1}$ For this reason too I avoid the labels "anti-Nicene" and "non-Nicene", which tend to normalise the "Nicene" position - rarely identified as such by contemporaries - as an orthodoxy against which all others are ranged, and thus accepts and enshrines a perspective which was anything but neutral in its day. ${ }^{2}$ I am concerned here above all with the rhetoric of Ambrose of Milan

* I am grateful to the Alexander von Humboldt Foundation for providing me with the opportunity to research and write this article. In addition, I am indebted to the editor and the journal's anonymous reviewers for their comments and suggestions, and to Hartmut Leppin for his generosity in reading and commenting on an earlier draft. Any remaining errors of fact and interpretation are my own.

1 Williams (1996) 338. It is therefore better to restrict "homoian" and equivalent labels to those bishops and theologians who explicitly set out their views in these terms; but even in this case, it must be recognised that "homoians" are united not by any positive doctrinal belief but by a preference for a particular compromise statement, intended to embrace belief in a consubstantial Father and Son as well as alternative views that expressed the relationship as one of likeness or similarity.

2 Cf. Williams (1996) 336; for similar reasons, Gwynn (2007) prefers to use the contemporary polemical 
as he represents his enemies within and without the city, and I prefer to avoid lending spurious precision to a term - "Arians" - which he uses rather indiscriminately. ${ }^{3}$ My purpose is in any case not to establish the beliefs of those he identifies as his opponents in the basilica crisis of $385 / 6$, but instead to ask whether he represents them - as has often been supposed - as members of a rival congregation among the Christians of Milan; and whether, if not, there is any strong reason for modern scholars to believe in the existence of such a rival congregation, if the progress and later portrayals of the crisis can be sufficiently understood without it.

It is conventionally supposed that Ambrose of Milan, as bishop, presided over a city divided into rival congregations: that his own "orthodox" or "Nicene" community was confronted by a hostile "Arian" community with a coherent doctrinal identity and agen$\mathrm{da}$, as well as its own clergy and periodically its own claimant to the episcopal throne. This view was influentially set out by Michel Meslin in 1967, as part of his effort to reclaim western "Arianism" as a once-viable alternative to what would become orthodox Christianity. ${ }^{4}$ The implications of Meslin's proposals for our understanding of Ambrose of Milan were only fully worked out in the mid-199os, with the publication in rapid succession of an influential article by Harry O. Maier and monographs by Neil McLynn, Daniel H. Williams and Christoph Markschies. ${ }^{5}$ All accepted the general picture of Milan under Ambrose as divided into rival factions on the basis of doctrine; although the monographs in particular are careful to replace the tendentious and partisan label of "Arian" for Ambrose's opponents with the theologically more precise "Homoian" (or its variants). ${ }^{6}$ This position has now become the dominant view, and any anxiety about the fact that, as McLynn has observed, '[w] e receive only occasional glimpses of this homoean church-in-waiting in Milan' can be lessened by supposing that such a movement must necessarily be secretive, and was doubtless driven further underground by perse-

term "Eusebians" for those attacked by Athanasius and his allies, rather than accepting a misleading characterisation of their precise doctrinal position(s).

3 In fact, even in his doctrinal treatise De fide, Ambrose is notable for his (perhaps deliberate) misuse of theological terminology and categories. It is now widely recognised that Ambrose's strategy in this work and in other confrontations over doctrine was primarily to misrepresent his opponents: Hanson (1988) 669-75; McLynn (1994) 103-4; Williams (1995) 144-8; Markschies (2005) 54-9.

4 Meslin (1967) 44-58; thus the comments of Williams (1995) 2: 'Meslin's major achievement was to show how western Arianism, like Nicene Christianity ... produced within its own communities a whole range of devotional, exegetical, and polemical literature. These documents stand as strong witnesses to the internal vigour of their faith.'

$5 \quad$ Maier (1994); McLynn (1994); Williams (1995); Markschies (1995). McLynn uses Maier's article, but for the most part these authors seen to have worked largely independently of one another.

6 Thus Maier (1994) 74: 'the opposition was between an Arian community, devising its strategy and meeting for worship in private, and a bishop jealously guarding the city's basilicas'; McLynn (1994) 57: 'Ambrose also had to deal with considerable open opposition', subsequently defined as including 'the Arians' at 58, cf. also 184-6; Williams (1995) 7: 'Detailed study of Ambrose's election to the Milanese episcopacy (374) and the years following reveals a figure who was often hard-pressed by his Homoian adversaries'; largely taken for granted in Markschies (1995) 84-212, who comments explicitly on this fundamental division only when a new faction enters the scene, e.g. 134: 'Neben der homöischen und nizänischen Gemeinde etablierte sich am Ort eine weitere schismatische Gruppe .... 
cution. ${ }^{7}$ Indeed, it is notable that expressions of doubt about the size and significance of any doctrinal opposition to Ambrose among the Christians of Milan - as for example by Peter Iver Kaufman - have been dismissed and even derided. ${ }^{8}$ Nevertheless, it is possible to remain sceptical about the power and influence of this elusive underground movement. ${ }^{9}$ My intention here is to raise some doubts regarding the accuracy of such a model of Milan under Ambrose: not on the grounds of new evidence, but in the hope of distinguishing as clearly as possible between the evidence we have and the presuppositions by which it is interpreted..$^{10}$ It is at least important to acknowledge a silence before rushing to fill it with argument.

There are various occasions on which this oppositional faction is believed to emerge into the historical record during Ambrose's first decade or so as bishop of Milan. In the space available it will make most sense to focus on the "basilica crisis" of $385 / 6$, since this episode has become the showpiece exhibit in accounts which emphasise doctrinal conflict." The initial request for the use of a basilica came from the court of the emperor Valentinian II, and traditionally it was understood as part of a campaign against Ambrose led by the emperor's mother, Justina, with the support of "Arians" among her advisers and courtiers. ${ }^{12}$ More recently scholars have begun to suppose that the prime beneficiaries, if not the actual instigators of the request for a basilica, were to be found among a local "Arian" opposition, and Maier in particular insisted on the role of such a group (and its "bishop") in 'catapulting the court to appropriate a church to house the Arian community.'13 Indeed, the request for a basilica is now commonly explained precisely as

7 McLynn (1994) 185; Maier (1994) 81-2, relying on the fifth-century Opus imperfectum in Matthaeum and on the rhetoric of imperial laws against heresy; but see now the interpretation of such claims in Bowes (2008) 193-6. The position of Maier is explicitly followed in e. g. Burrus (1995) 87, Davidson (2002) 65-8, Gwynn (2010) 253-5 and Kalleres (2015) 202-26; that the Christian population of Milan was divided into doctrinal factions is also supposed, without any explicit reference to the works discussed here, in Krautheimer (1983) 72, Lancel (2002) 77, Liebeschuetz (2005) and Sizgorich (2009) 60. Examples could be multiplied further.

8 Thus the mere suggestion in Kaufman (1997) that the extent and significance of doctrinal opposition to Ambrose at his election had been overstated was published only alongside rebuttals by McLynn (1997) and Williams (1997); that suggestion is also the target of the bald assertion in Davidson (2002) 66 that " $t$ ] he strength of these hostile forces continues to be underestimated by one or two scholars, but it was in fact considerable' and is derided in Barnes (2002) 235 as 'strange (and anachronistic)'.

9 Some scepticism regarding the prominence given by McLynn and Williams in particular to doctrinal opposition in Milan is provided in Duval (1998); his points have largely been ignored.

10 A similar case is made in Drinkwater (1983), who likewise casts doubts on explanations which depend on the activities of "underground" movements which largely eluded contemporary sources.

11 No detailed chronology of the crisis is here required. There are essentially two major interpretations: one, deriving from Seeck (1913) 200-3, 515-8 and modified by van Haeringen (1937), now best set out in McLynn (1994) 181-208; and the other, deriving from the Maurist editors of Ambrose's letters, now best set out in Barnes (2000). I am inclined to accept the latter, but nothing in this article depends on it.

12 E.g. Homes Dudden (1935) 270; Paredi (1964) 145. Justina's responsibility for instigating the crisis is asserted at Marcos (1997) 147-8, not to blame her for heresy but to credit her for her independence.

13 Maier (1994) 85; McLynn (1994) 184 is more cautious, suggesting that the local "Arians" were 'at best incidental beneficiaries'. Ramsey (1997) 23-9 refers primarily to opposition to Ambrose from within the imperial court, but his comment that in 386 ' $[\mathrm{a}] \mathrm{n}$ Arian mob attacked the Portian basilica' (28) implies a collaboration with a popular faction; something of the same alliance seems to be envisaged in Colish (2002) 361-3, identifying a "court party" but also an "anti-Nicene" immigrant community; Liebeschuetz 
a result of the need of this marginalised, dissident community for a basilica of its own, in which to celebrate Easter and carry out baptisms. ${ }^{14}$ Interpreted this way, the basilica crisis becomes the episode in which the "Arian" opposition to Ambrose emerges most clearly into the light, and experiences its greatest success. It justifies an understanding of late-antique Milan as irrevocably divided between "Nicene" and "Arian" factions, and in which conflict was embedded and unavoidable. ${ }^{15}$ And far from celebrating the variety and vibrancy of early Christian culture, it instead imposes a narrative of civil warfare and the triumph of orthodoxy on a situation which was surely more complicated.

To isolate a single incident in this way is artificial, of course. Nevertheless, its interpretation in modern scholarship has so often depended on assumptions derived from other episodes, themselves not entirely secure, that it will be valuable to examine it without appealing to that established background. This means taking no account of the well-known narratives in Paulinus and Rufinus of Ambrose's election as bishop in $374 .^{16}$ It means ignoring the doubtful insinuations of two letters from the Council of Aquileia in 381 , which refer to the mysterious activities of a renegade bishop, Julian Valens, who is offered as an "Arian", a barbarian sympathiser and traitor, and an ally of the ultra-orthodox antipope Ursinus, as well as, for good measure, the Jews. ${ }^{17}$ And it means setting aside cryptic references to an earlier dispute over a basilica in 381 , which involved the emperor Gratian but about which little more can be known. ${ }^{18}$ This is not to suggest that these episodes are irrelevant to an understanding of Milan during Ambrose's time as bishop, but only to acknowledge that they each require careful discussion at a length not available here. ${ }^{19}$ For present purposes it will suffice to focus on this single incident and to judge whether or not the evidence justifies the interpretations placed upon it. If not, then we may be entitled to ask whether these other incidents are not equally questionable.

It should be recognised, too, that the basilica crisis is the episode in Ambrose's career for which we have the most direct contemporary evidence. The events of $385 / 6$ receive passing mentions in the Confessions of Augustine of Hippo, who was in Milan at the time, and in the sermons of Gaudentius of Brescia, who seems to have learned of them from an eye-witness. ${ }^{20}$ They are also presented in the Life of Ambrose of Paulinus of Milan and in the Church History of Rufinus of Aquileia, both relatively proximate sourc-

(2005) 129 gives Justina a leading role but assumes the involvement of 'the Arian community of Milan' and their (supposed) bishop.

14 The need for a basilica to carry out baptisms is made the motivation for the crisis in Williams (1995) 209-10, and is used to explain the choice of the Portian Basilica in Colish (2002).

15 Two recent examples are Lusuardi Siena and Neri (2013) 147, who speak of 'le due fazione' and consider that the court 'risponde alle esigenze della comunità ariana'; and Kalleres (2015) 200-2, for whom 'Christians on both sides $\mathrm{dr}[\mathrm{e}] \mathrm{w}$ lasting battle lines' forming 'a network of interlinking dualisms that rip[ped] apart the city as thoroughly as it divide[d] Milan's populations'.

16 Paul. Med. V. Amb. 6; Ruf. HE XI.11. See McLynn (1994) 1-13, 44-52, Williams (1995) 104-27 and Barnes (2011); cf. also the exchange between Kaufman (1997), McLynn (1997) and Williams (1997).

17 Amb. Ep. ex. coll. $4[10] 9-10 ; 5[11] .3$.

18 Amb. De spir. sanct. I.1.19-21. The reconstruction in Williams (1993) is necessarily speculative; cf. the accounts of Gottlieb (1973) 40-51 and McLynn (1994) 120-3.

19 I offer a more thorough account of Ambrose's dealings with "Arians" in Williams (2017).

20 Aug. Conf. IX.7.15; Gaud. Brix. Praef. ad. Beniuolum 5. 
es and potentially well-informed. ${ }^{21}$ For the most part these tell the same story: that of the traditional version, placing Justina and the court at the centre of events and making very little mention of an "Arian" opposition. The implications of this evidence will be discussed towards the end of this article. But the case for the significance of the "Arian" opposition has been made above all on the basis of Ambrose's own writings, in the form of two letters - one to his sister Marcellina, one to the emperor Valentinian - and the text of a sermon included with the second of these. ${ }^{22}$ These derive from the very midst of the crisis, and do not represent neutral observations so much as an effort to shape events as they developed. The letter to the emperor concentrates on political and legal arguments; the sermon, meanwhile, concentrates on discrediting the bishop who had evidently been advising the court. Both make insinuations about the role of doctrine in the crisis, but in a remarkably indefinite manner; and as we shall see, they represent "Arianism" as wholly foreign to Milan. Initially, however, I will focus on the letter Ambrose wrote to his sister, which should offer the most valuable testimony, and which proffers an explanation of the nature and course of the crisis and provides a more-or-less continuous narrative.

\section{The Case of Castulus}

This letter was addressed by Ambrose to his sister Marcellina in Rome, and was ostensibly written in the days around Easter 385 or $386 .{ }^{23}$ The letter describes the course of events from the Friday before Palm Sunday to the Wednesday or Thursday of Holy Week; they begin with the demand of certain uiri comites consistoriani who request the use of a basilica in Milan, evidently for the celebration of Easter. ${ }^{24}$ For our purposes the identity of the basilica in question is unimportant, but it should be noted that the demand originates with the court. Indeed, Ambrose relates that the following day the Praetorian Prefect came in person to renew the request. ${ }^{25}$ And the court continues to take the initiative, and to prepare for a distinctively imperial occasion: Ambrose reports that on Palm Sunday imperial hangings, uela, are set up in the disputed basilica; and when the basilica is subsequently occupied in protest by ordinary Milanese Christians, soldiers are sent to surround it and before long to enter it and to prepare for the advent

21 Paul. Med. V. Amb. 11-15; Ruf. HE XI.15.

22 Amb. Ep. 76[20]; 75[21]; 75a[21a]. The sermon, also known as the Sermo contra Auxentium, is said in its title to have been enclosed with the initial dispatch to Valentinian, although Barnes (2000) 287-8 argues plausibly that it was delivered only after that letter was sent; Liebeschuetz (2005) 37 similarly suggests that it was in fact attached only at a later stage.

23 Amb. Ep. 76[20], belonging to 385 on the reconstruction of Barnes (2000) and to 386 on that of McLynn (1994); it is very likely that, as with his later letter 77 [22] on the discovery of the martyrs Gervasius and Protasius, also directed to Marcellina, the account was meant to be more widely circulated: thus Liebeschuetz (2005) 134 .

24 Amb. Ep. 76[20].2: the CSEL editor supplements uiri with illustres.

25 Amb. Ep. 76[20].3. 
of the emperor. ${ }^{26}$ The consistent use in this connection of the verbs prodire and especially procedere, along with the words Ambrose places in the emperor's mouth in his letter - 'I too ought to have a basilica!' - suggest that the intention was to procure a basilica for the emperor to proceed to in state. ${ }^{27}$ And it seems clear that the plan was for only a temporary sequestration of the basilica, encompassing a single service or a short series of services. ${ }^{28}$ The fundamental picture provided by Ambrose is of an initiative taken by the court to appropriate a basilica for an imperial celebration of Easter: one which would take place in public, but which would not be under the control of Ambrose as the city's bishop.

None of this, it should be clear, requires the existence or the involvement of a local dissident community among the Christians of Milan. Ambrose in this letter never in fact refers to any such community, nor indeed to any "Arians" or doctrinal dissidents of any description who are not directly associated with the imperial court. The one obvious exception is Ambrose's account of an early stage of the crisis, on Palm Sunday, as the imperial hangings were being set up in the disputed basilica. As unsettled supporters of Ambrose made their way to the basilica to occupy it, they encountered by chance 'a certain Castulus, whom the Arians regard as a priest', and took hold of him as a prisoner. ${ }^{29}$ Ambrose insisted that this man should be freed for the sake of avoiding any bloodshed; or at least, he adds, to ensure that the only blood shed would be his own, on behalf of both the populus and the impii..$^{\circ}$ This division between the populus and the impii has been taken to mean that Milan was divided into doctrinal factions: the former being Ambrose's people, the latter being ministered to by Castulus and others unknown. But this is a lot to build on a single reference to a passing priest whom Ambrose represents as an innocent bystander. And it is also to take the reference to impii as though it were simply another word for Arriani - and so to risk overlooking the subtlety of Ambrose's representation of events. ${ }^{31}$

No doubt for Ambrose "Arians" were also impious. But here the impii are presumably those making preparations at the basilica, who have been established at this stage as direct agents and officials of the imperial court. Whether or not Castulus had anything to do with them, the fact that Ambrose's supporters seized upon him suggests that they believed he had; and the effect is to imply either that Castulus was associated with the court or that the court was associated with "Arians" - if not both. Yet even this association is not made directly: we are meant to recognise the insinuation, but Ambrose deliberately keeps some deniable distance between emperor and heretics. The same

Amb. Ep. 76[20].4-11; on the significance of the uela in particular, see Nauroy (1988) 77-9, McLynn (1994) 188 and Barnes (2000) 285-6.

Amb. Ep. 76 [20] 19: '“debeo et ego unam basilicam habere."' Nauroy (1988) 52 n.148 notes the use of prodire and procedere and concludes that an imperial procession is envisaged; the point is accepted and extended at Liebeschuetz (2005) 129.

28 Thus Liebeschuetz (2005) 129.

29 Amb. Ep. 76[20].5: 'Castulus quendam, quem presbyterum dicerent Arriani'.

30 Amb. Ep. 76[20].5: 'non solum populi, sed etiam pro ipsis impiis'

31 Liebeschuetz (2005) 163 elides the distinction in his translation, in which the impii are simply "the Arians". 
tactic is on show when, in writing to Valentinian on a separate occasion in this ongoing basilica crisis, he justifies his refusal to hand over a basilica to the emperor by the fear that it will be subsequently handed over to "Arians": evidently the emperor's request is at least pretended not to amount to that in itself. ${ }^{32}$ Valentinian himself is never said to be a heretic: indeed, he was unbaptised at the time. And Ambrose was evidently not eager to make accusations of heresy against the emperor, or even directly against his advisers. ${ }^{33}$ The capture of Castulus hints at a link between the activities of the court and an "Arian" agenda, without making a definite connection between them.

Hence the brief mention of Castulus may reveal that Ambrose wanted to cast his opponents as "Arians". But it tells us very little about the nature and place of such "Arianism" in Milan. Certainly nothing in the text requires that Castulus represented or ministered to an "Arian" community in the city itself; nor that the "Arians" who consider him a priest are a specific body of Milanese heretics rather than "Arians" in general. If we take seriously the logic of those who apprehended him, given the information in Ambrose's letter, we would be more inclined to associate him with the court - to suppose, with Frederick Homes Dudden, that Castulus was 'probably one of the court chaplains.'34 But even if Ambrose is merely seizing upon the incident to make a subtle connection between the court and the "Arian" threat, it is possible to find other explanations for the presence of an "Arian" priest in Milan: whether as a cleric attached to a private household, or as no more than a visitor or messenger to what was a cosmopolitan imperial city. Neither would be uncommon in late antiquity, when priests served regularly as letter-carriers and when private worship was widespread enough to attract frequent attention from emperors and bishops..$^{35}$ That Castulus did not belong to Ambrose's church does not justify building a rival church around him; and that Ambrose emphasises that the crowd encountered him in the streets scarcely suggests that he played any active role in events at the basilica. ${ }^{36}$ At the very least we should recognise that the only "Arian" mentioned by Ambrose who cannot be proved to be a foreigner - indeed, the only "Arian" openly identified as such by Ambrose - is explicitly said to be wholly uninvolved.

33 His defiance of the emperor's agents in the heated encounters reported later in the letter must be distinguished from his careful insistence that the emperor himself is not personally to blame but is only misguided: this aspect of Ambrose's rhetoric is rightly emphasised at Nauroy (1988) 59.

34 Homes Dudden (1935) 274.

35 For private worship in late antiquity, see Bowes (2008), including at 80-2 the example of Ambrose in Rome conducting a private service without authorisation from the local bishop; Bowes (2008) 74 also comments on the independent ministers and ascetics who could be found in major cities. The examples of Martin of Tours and Hilary of Poitiers under Ambrose's predecessor Auxentius show that ascetics and bishops could appear in cities without the approval of the local bishop, and without requiring any local support base of their own; for priests as letter-carriers, see e. g. the early career of Sabinus of Placentia, at PCBE II: 'Sabinus I', as well as numerous examples in the letters of Paulinus of Nola and Augustine. 


\section{3. "Catholics" and "Arians"}

Throughout the rest of this first letter Ambrose continues to present the situation as a dispute between himself as bishop and the imperial court and its agents. The sermon which dominates the latter half of the letter is built on this clash between emperor and church: its leitmotif is the claim he puts in the mouth of Valentinian that he is the ultimate owner of the buildings of the empire; and Ambrose's response, that he will render unto Caesar what belongs to Caesar, but that basilicas belong to God..$^{37}$ The letter culminates with Ambrose accused by the emperor - or his notarius - of being a usurper (tyrannus), and with the threat of the emperor's chamberlain, Calligonus, to have Ambrose executed for lèse-majesté..$^{8}$ These give an accurate sense of the way that the whole crisis is presented in political terms: none of these figures is presented as acting with a doctrinal agenda, but as defending the right of the emperor to the use of a basilica in the city. The same is true of Ambrose's encounter with some 'tribunes of the Goths', who are presented not as acting out of doctrinal fervour but as the military enemies of the empire, undermining it now from within. ${ }^{39}$ The only occasion, aside from the unanticipated seizure of Castulus, on which Ambrose implies an "Arian" agenda underlying the actions of the court comes before the sermon begins, at a point at which the disputed basilica has been surrounded by soldiers.

Ambrose's account of this situation is our only direct evidence for the presence of "Arians" in Milan during the basilica crisis. It will be given in Latin and then in my own translation:

idque a militibus imperatori mandatum dicitur, ut si prodire uellet haberet copiam; se tamen praesto futuros si uiderent eum cum catholicis conuenire, alioquin se ad eum coetum quem Ambrosius cogeret transituros. prodire de Arrianis nullus audebat quia nec quisquam de ciuibus erat, pauci de familia regia, nonnulli etiam Gothi. ${ }^{40}$

It is said that the soldiers sent word to the emperor that if he wished to come forth he had their support; that they would stand by him if they saw him joining the catholics, but that otherwise they would go over to the assembly convoked by Ambrose. None of the Arians dared to come forth, since none were there from among the citizens, only a few of the imperial household, and also some of the Goths.

The use of prodire in the first sentence is in line with the rest of the letter, and maintains the impression that the basilica was required for the sake of court ceremonial. ${ }^{41}$ What must be addressed here is the use of the term catholici: the soldiers, here found unexpectedly dictating conditions to the emperor, will secure the basilica for him only if he

Amb. Ep. $76[20] .2,8,19$. The same rhetoric dominates the second letter, dealing with a second siege: Amb. Ep. $75 \cdot[21] .5,17-18,30,35$.

38 Amb. Ep. 76[20].22, 28.

39 Amb. Ep. 76[20].9: 'gothi tribuni'.

40 Amb. Ep. 76[20].11-12.

41 See above, n.26.

This material is under copyright. Any use outside of the narrow boundaries of copyright law is illegal and may be prosecuted.

This applies in particular to copies, translations, microfilming

as well as storage and processing in electronic systems. 
worships alongside the "catholic" Christians of the city, but otherwise will go over to the service called by Ambrose. The association of these "catholics" with Ambrose is strongly implied, but it should be noted that the demand is not that the emperor should invite Ambrose to conduct the imperial mass itself: it seems possible to envisage a "catholic" service at which the bishop did not preside. ${ }^{42}$ But more than that, we must ask whether the intention was in fact to distinguish a "catholic" congregation in Milan from an "Arian" one. If so, we have the remarkable spectacle of soldiers not only dictating to their emperor, but unilaterally intervening to take sides in a local doctrinal dispute.

But did "catholic" have the accepted meaning of "Nicene" in Milan in 386? It was, after all, not a neutral term but a tendentious claim to universality. ${ }^{43}$ Certainly it was used in the fourth century by propagandists such as Hilary of Poitiers and Lucifer of Cagliari to refer to their own "orthodox" faith, and was extended to apply to the individuals and groups whom they considered to be their allies. ${ }^{44}$ And a step towards a more authoritative definition may perhaps be seen in a law of Theodosius I of 380 , which restricted the name of "catholic" to those aligned with Damasus of Rome and Peter of Alexandria. ${ }^{45}$ This law was issued to the people of Constantinople, however, and seems not to have been applied in the west, even by Theodosius himself. ${ }^{46}$ Individuals and groups defined as heretical by such rhetoric and such laws continued to call themselves - and consider themselves - "catholic": examples include Priscillian of Avila and, most strikingly, Palladius of Ratiaria, the latter explicitly in opposition to Ambrose. ${ }^{47}$

The case was different in North Africa, where Augustine of Hippo subsequently distinguished "catholics" from Manichees and especially "Donatists", and could claim that their opponents even recognised the label..$^{4}$ But Augustine's later use of the term should

43 The TLL s. v. 'catholicus' notes its dual meanings of "orthodox" and "universal", both present in Christian Latin from Tertullian onwards; see also Schindler (1986-94) 815. Perrin (2010) 212-4 notes both the efforts in the fourth century AD to claim "catholic" as defining a particular faction and the inevitable contests that resulted over the proper application of the term. The ambiguity of "catholic" and its overlap with related questions of "schism", "orthodoxy" and "heresy" is also discussed in Whiting (2011), esp. 35-9.

44 Thus e. g. Hil. Pict. Syn. 34, 45; Luc. Cal. Athan. 1.42, Jerome Ep. 61.2, Ambrosiaster, In 2 Tim. 2:16-17; as a label for individuals and groups, see e. g. Hil. Pict. Syn. 7, 56, Hil. Pict. ad Const. 1.2, Luc. Cal. Athan. 2.3. Not all of these uses designated the same group as "catholic".

45 CTh 16.1.2, defining "catholic" Christians as those aligned with the Trinitarian formula of Damasus of Rome and Peter of Alexandria, and all others as heretics; cf. CTh 16.5.11 (385), which also envisages a faction at Constantinople recognised by the authorities as "catholic".

46 For the restricted application of the law, see Soz. HE VII.4, who attempts to excuse it. Errington (1997a) 36-41 and (1997b) 411-16 confirms that it is unlikely to have applied in the west prior to the arrival of Theodosius; and the emperor's acceptance of Luciferian petitioners as "catholic" at Coll. Avell. 2a, in 384, suggests that even then this status did not depend on communion with Damasus or any other bishop but on the emperor's own judgement.

47 Thus Priscill. Tract. 1.4 (defined against Patripassianism); Scholia ariana 336v, 45 [= Pall. Apol. 84]: 'cur praeterea ab imperatore ueniam postulas, cum ne tu impiaetiatis arguaris eius precepto nullus catolicus ueritatisque doctor aduersum te a quoquam audiatur?'. For comment on the latter passage see McLynn (1994) 101, who understands the "catholics" here to be 'the homoean community in Milan'.

48 Schindler (1986-94) 816 finds Augustine borrowing the term from Optatus of Milevis, in response to conditions in north Africa; Alexander (2008) 365 notes its emergence in Augustine's writings from 387 onwards, especially in contradistinction to Manichees; Marone (2007-8) traces its use in the Donatist 
not lead us to suppose that Ambrose commonly used it to distinguish his own community from another in Milan. In fact, his use of "catholic" is relatively rare for one apparently engaged in a battle against a rival community: and only in the context of eastern affairs, in two letters addressed to Theodosius I and picking up the language of his law, does it differentiate rival congregations in the same city. ${ }^{49}$ In the letters and sermon deriving from the basilica crisis Ambrose uses it on only one other occasion, imagining the court's intervention to require the exile of "catholic" bishops in cities across the empire..$^{\circ}$ And in this case the point is certainly not that these bishops all belong to contested sees, but that the court of Valentinian is setting out its stall in opposition to the universal faith.

It is important to recognise, therefore, that the term catholici was not at this stage established as the conventional designation of a particular partisan group in Milan. If the use of the term by the soldiers is attributed to Ambrose rewriting or paraphrasing their plea to the emperor, then no doubt he would have meant to imply that the "catholics" were to be identified with the Christians of Milan in communion with himself as bishop. Indeed, in this connection it is quite possible that he had in mind the law of Theodosius - which reserved church buildings for the exclusive use of "catholics". But Ambrose's identification of his own congregation as "catholic" does not require or even imply the presence of a rival, "Arian" congregation. It can be sufficiently understood as a claim to represent the universal church, from which the emperor risked separating himself if he insisted on worshipping apart. There is no need to see the advice to Valentinian as presenting a choice between factions in the city; it is enough to recognise it as a warning not to cut himself off from the faith of the Milanese Christians as a whole.

If the term originated with the soldiers themselves, this is even more likely to have been the message. It is more difficult to imagine them making demands of the emperor in this way on behalf of a faction, than it is to suppose that their aim was to reconcile him with the bishop and the public at large. Certainly some were baptised and in communion with Ambrose, and would later join the crowd in the basilica. ${ }^{51}$ But enough remained on duty that it was only the next day that the siege was finally lifted. ${ }^{52}$ We might choose to identify the groups who stuck to or abandoned their posts with, respectively, the Goths

controversy. Aug. c. Gaud. 2.2 explicitly contrasts "catholic" universality with the limited horizons of the Donatist church. But even so we should not too easily credit the claim at Aug. uera rel. 7.12 on his own faith, that 'catholica nominatur, non solum a suis, uerum etiam ab omnibus inimicis'.

49 Amb. Ep. ex. coll. 6[12].1 ("catholics" persecuted by "Arians" in the east, especially Constantinople), 4 (Timothy of Alexandria and Paulinus of Antioch), 5-6; Amb. Ep. ex. coll. 9[13].1 (Constantinople), 2 (Antioch), 5 (Constantinople). These two letters account for fully half of the occurrences of catholic* in Ambrose's writings; to them may be added another occurrence in a letter from Aquileia, Amb. Ep. ex. coll. 4[10].12, in which the contrast is with Photinians in Sirmium on the very eastern edge of the western provinces; Amb. Ep. 56[70].2, again in reference to Antioch; Amb. De exc. fratr. I.47, where "catholic" implies communion with Rome but in the context of the Luciferian schism; and Amb. De spir. sanct. III.17.129, where "catholics" are indeed distinguished from "Photinians" and "Arians" in general. The remaining uses, Amb. De fide I.18.120 and II.16.139 and Amb. Hex. 3.1.3, denote the universal church.

50 Amb. Ep. 75a[21a].16: 'per ecclesias iubentur eici catholici sacerdotes'.

51 Amb. Ep. 76[20].13: as Williams (1995) 215 n.114 points out, for the threat to have meaning these soldiers must have been not only loyal to Ambrose's community but baptised members of it.

Amb. Ep. 76[20].24 (soldiers prevent Ambrose from leaving the basilica), 26 (troops ordered to leave). 
and diuersarum nationum uiri whom Ambrose claims were sent by the court; but if this is to be taken as corresponding to distinct doctrinal identities, we must explain how they could both be party to the demand made of Valentinian; or else how one group could act alone and expect to avoid any trouble with the other. ${ }^{53}$ Indeed, if we suppose that the basilica was sequestered for openly partisan reasons, we may ask why the court would have sent so mixed and unreliable a force, when Gothic and therefore presumably solidly "Arian" soldiers were available. ${ }^{54}$ Either the court was remarkably short-sighted in sending strongly "Nicene" soldiers to carry out its "Arian" agenda, or there were not enough "Arian" soldiers and sympathisers in Milan to secure a single basilica. Ultimately it seems more likely that the basilica was being secured for imperial use, and that the soldiers hoped to reconcile the emperor with the people as a whole. The catholici here are the Christians of Milan, not a single faction or congregation.

The inability of the court to secure a basilica, and the apparent shortage of sympathisers in Milan to help them do so, must therefore cast doubt on the presence of a significant "Arian" community among the Christians of Milan. Ambrose's next sentence reinforces that doubt: prodire de Arrianis nullus audebat quia nec quisquam de ciuibus erat, pauci de familia regia, nonnulli etiam Gothi. For centuries this was unproblematically read as a denial that there were any "Arians" among the Milanese citizens: examples of such readings in English would include the translations of Henry Walford (1881) - 'Not a single Arian dared come out, for there were none among the citizens' - and Mary Melchior Beyenka (1954) - 'No one among the Arians dared to appear, for there were none among the citizens. 55 This was also the interpretation adopted by Homes Dudden and by Hans von Campenhausen, and more recently by Gérard Nauroy and Yves-Marie Duval. ${ }^{56}$ The more recent English translation of J. H. W. G. Liebeschuetz reinterprets this sentence, however, and adds a note of explanation, proposing that it refers to 'the composition of the force occupying the cathedral'.57 His version thus runs as follows: 'Not one of the Arians was brave enough to come out, since there were none of the citizens there, a few from the imperial household, and a number of Goths'. ${ }^{8}$

The sentence is indeed ambiguous: nec quisquam de ciuibus erat can mean that 'there were none from among the citizens' or that 'none of the citizens were there': I have tried

53 Amb. Ep. 76[20].20; McLynn (1994) 192 n.110 has the message sent by 'a group of soldiers', but the text has only a militibus and it is unclear how a group of the soldiers could either claim to guarantee the emperor's safety or dare to dictate to him in opposition to their comrades.

54 Nauroy (1988) 55 n.157, noticing the problem, suggests that Goths were a minority in Valentinian's army; but this is rejected by McLynn (1994) 192 n.119.

55 Walford (1881) 131; Beyenka (1954) 368.

56 Thus Homes Dudden (1935) 271 ('there were practically no Arians among the townspeople'); von Campenhausen (1929) 203 ('es hatten sich nur "einige Goten" der kleinen ketzerischen familia regia angeschlossen'); Nauroy (1988) 52 ('aucun citoyen milanais n'appartenait à cette secte, qui n'aurait eu pour fidèles que quelques membres de la famille royale et quelque soldats goths'). Duval (1998) 29 is less trenchant but also calls attention to Ambrose's minimising of the "Arian" presence among the citizens: 'il n'y avait personne qui appartint á la Cité. We might go back as far as LeBeau (1824-1836) IV.303: Auxentius 'ne comptait entre les siens aucun des habitants de la ville'.

57 Liebeschuetz (2005) 165 n. 5 .

58 Liebeschuetz (2005) 165. 
to retain the ambiguity in my own translation above. But the version here adopted by Liebeschuetz evidently also responds to a desire to avoid having Ambrose deny that there are "Arians" among the citizens of Milan. For those committed to the presence and role of a local "Arian" faction or congregation, this is an awkward declaration. Yet the translation of Liebeschuetz, although possible, seems a less natural reading of Ambrose's Latin.99 We may add that his translation also requires that the soldiers at the basilica could be described by Ambrose as consisting of only 'a few Goths' - which fits awkwardly with the mixed force he subsequently describes, and also with the fact that at least some of them were evidently in communion with him..$^{60}$ Above all, it makes Ambrose's explanation difficult to understand: it is unclear why any "Arians" among the population would be intimidated by the absence of citizens at the basilica, or by the presence of Goths and courtiers, since Liebeschuetz's reading supposes that it was precisely the court and its army who were collaborating with the "Arian" faction against the wider population. This was surely the opportunity that the supposed "Arian" congregation had sought.

Neil McLynn, likewise committed to a substantial "Arian” presence among the citizens of Milan, seems to recognise the problem and explains that the "Arians" did not show themselves because the basilica in question had not yet been cleared of citizens loyal to Ambrose. ${ }^{61}$ But this makes it hard to see what Ambrose's statement is then supposed to mean: he can be saying neither that there are no "Arians" among the citizens, nor that no citizens are at the basilica. This reading would also contradict Ambrose's earlier comment that the basilica had been surrounded and occupied by soldiers, and their evident confidence that they could guarantee the emperor's safety - which would surely be unwarranted if the basilica was still filled with a mob of citizens loyal to Ambrose. ${ }^{62}$

Other scholars invested in the presence of an "Arian" population in Milan get around this explicit statement by Ambrose in different ways. Maier, for instance, does not discuss it at all - although he offers instead, as admittedly 'circumstantial evidence' of the existence of a rival "Arian" congregation, the rather broad and generalised warnings against heretics in various of Ambrose's sermons. ${ }^{63}$ One more recent account takes liberties with the translation to the extent of reading it as a positive declaration from Ambrose that there was indeed an "Arian" community in Milan, consisting of 'alcuni cittadini, pochi legati all'imperatore, i soldati goti'.64 The most scrupulous engage with the text and

This is of course open to debate; but an example in which Liebeschuetz's reading would be highly unnatural may be seen in Machiavelli (1588), the first Latin translation of Machiavelli's Discourses on Livy, in which 'non trovò ... uomo che fusse stato mai in guerra' (I.21) is given as nec quisquam ciuium erat, qui umquam in bello fecisset: there were none among the citizens who had ever been in a battle, not that none of those who had been in a battle were present.

60 As noted above, McLynn (1994) 192 n.110 accepts that the forces occupying the basilica were a mixed group, with one faction sending the message to Valentinian; Ambrose must therefore be presumed to have been simplifying their status here.

61 McLynn (1994) 192.

62 Amb. Ep. 76[20].11: 'circumfuso milite occupatur basilica'. For discussion of what exactly this phrase implies, see Nauroy (1988) 48-51 and Lenox-Conyngham (1982) 358-9; but it must surely mean that the basilica had been secured and no longer harboured supporters of Ambrose.

63 Maier (1994) 75-6.

64 Lusuardi Siena and Neri (2013) 147. 
accept something more like the traditional reading, but understand it as Ambrose misrepresenting his "Arian" opponents as outsiders. ${ }^{65}$ Daniel Williams in particular reads the statement as an attempt 'to discredit his Homoian opponents by depicting them solely as those who belonged to the imperial retinue or as Gothic soldiers'.6 ${ }^{6}$ This concedes that Ambrose's claim was that there were no "Arians" among the citizens; which makes it odd that at an earlier stage in the same work Williams explicitly rejects what he calls 'Homes Dudden's biased assessment, that there was no Arian congregation at this time apart from "Arian courtiers, officials and soldiers"'. ${ }^{67}$ It is difficult to see why it is a more obvious indication of bias to accept what Ambrose wrote than to treat it as an obvious misrepresentation.

Of course, Williams's interpretation of Ambrose's comment relies on a wider investigation into the presence of this "Arian" community in Milan over a decade or more, and is treated by him here as an anomaly in a broader picture to which he is committed. Certainly we should not underrate the extent to which Ambrose was seeking to present these events in a particular and often self-serving way. But this reading leaves us all the same with the remarkable fact that Ambrose, in a comment aimed at contemporaries with first-hand knowledge of the situation, could make the easily falsifiable claim that there were no "Arians" among the citizens of Milan. The citizens of Milan did not need to be told who was responsible for the crisis, and so could overlook such misrepresentations. But at whom, then, was Ambrose's rhetoric aimed? It remains unclear why he should have sought to transform a dispute over doctrine, in which he could at least claim to be the competent authority, into a legalistic dispute over the emperor's property rights. If his goal was to marginalise his local opponents, it seems odd that he should so insistently have placed them among the power-brokers of the imperial court.

\section{City and Court}

The remainder of Ambrose's letter, and the other Ambrosian documents associated with the basilica crisis, follow a similar pattern. Ambrose continues to represent the dispute as between himself and the imperial court; and although he hints at the involvement of "Arians", his references are less concrete than they are often taken to be. The emperor's mother, Justina, is abused as a wicked adviser, but not directly accused of heresy; and even Ambrose's pointed mention of her Gothic entourage cannot be read as an unambiguous charge of "Arianism". ${ }^{68}$ Otherwise his attacks are centred primarily on Auxen-

65 For example, Lafferty (2003) 58: “None of the Arians dared to come out because not one was a citizen, few were from the royal household, but many were Goths”. .. Not only are the Arians barbarians, but they strive to make the church as barbarian as themselves'. Although the main argument here is unobjectionable, the translation perhaps overstates the number of Gothic "Arians" implied by Ambrose.

66 Williams (1995) 232.

67 Williams (1995) 210.

68 Amb. Ep. 76[20].12, 16-18: Justina is evidently the target of the various allusions to Eve, Jezebel and Herodias; and she is the femina ista whose retinue of Goths is presented as overturning the church. But as Heil 
tius, the visiting bishop whom Ambrose presents as collaborating with the court, and who is made the target of direct accusations of irresponsibility, bloodthirstiness, simony, and consorting with pagans and Jews. ${ }^{69}$ This last charge - which even Ambrose admits is speculative - then becomes the basis for a more distant association of Auxentius with "Arians", on the basis that anyone who might (even theoretically) mix with pagans and Jews would delight an "Arian" observer. ${ }^{70}$ The generic "Arian" invoked here is clearly imaginary, and throughout the crisis Ambrose continues to rely on these associations and insinuations without making direct charges even against Auxentius. Far from laying the blame for the dispute on a rival "Arian" congregation in the city, Ambrose is reluctant openly to identify his opponents - even at the imperial court - as "Arians".

It is of course highly likely that Auxentius held doctrinal views which differed from those of Ambrose. Nor is it to be denied that Ambrose intends to imply that Auxentius, and so by extension the emperor and his court, are promoting an "Arian" agenda. But the links made are all indirect. Auxentius is said to have demanded a basilica, which is clearly the case; but Ambrose, in asking to whom he is really being asked to hand it over, does not answer his own question but responds only by noting that the request has produced an outcry in praise of Christ, which maddens heretics and in particular "Arians". Elsewhere "Arians" are said to be heirs of the Jews, and worse than the Jews, in demanding that the rights of the Church are to be given to the emperor; but Auxentius is not placed among them..$^{72}$ There is no doubt about the implication, but Auxentius is not accused outright of any "Arian" allegiance. Even what seem the most direct accusations against him work primarily through suggestion: hence he is said to have changed his name to appeal to those who supported Ambrose's predecessor as bishop: the explicit identification of this first Auxentius as an "Arian" is as close as Ambrose comes to making that charge against his present opponent. ${ }^{73}$ And finally, in an addendum conspicuously out of place in the context of the rest of the letter, Auxentius is asked why he advocates rebaptism. ${ }^{74}$ This is far from securely established as an "Arian" practice at this time, and that the question is specifically about Auxentius's beliefs and not his actions implies that

(2014) 115 notes, there was not yet in this period 'a special identification of the Homoians with the Goths ... or vice versa', and Ambrose's remarks here should not be interpreted as though such a connection were obvious and inevitable.

69 Amb. Ep. 75a[21a].16, 18, 21, 23-4; for pagans and Jews, see also 26, 30 and Amb. Ep. 75[21].6, 26.

70 Amb. Ep. 75 [21].13: 'cum his plane conuenit Arriano qui creaturam Christum dicit, quod etiam gentiles ac Iudaei promptissime confitentur'. Amb. Ep. $75[21] .6$ admits that Auxentius has not revealed the names of the judges he has chosen, and both there and at Amb. Ep. 75a[21a] he admits that he may not have chosen any: their identity can therefore be no more than a matter of rumour and speculation.

71 Amb. Ep. $75 a[21 a] .17,19$.

72 Amb. Ep. 75 a [21a].30-31.

73 Amb. Ep. 75 a[21a].22.

74 Amb. Ep. 75a[21a].37. This final paragraph of Ambrose's sermon is so abrupt in its change of topic, and so out of keeping with the rest of the letter, that it may raise the suspicion that it was added at a later date. The revision of Amb. Ep. ex. coll. 1a for publication as Amb. Ep. 74[40] may offer a precedent: the most significant change is the addition of a final paragraph in the published version, consisting of a threat against the emperor which would have been difficult to defend in the original circumstances. For comment on this see Liebeschuetz (2005) 95-6, 111-12 and McLynn (1994) 308. 
no such baptisms had taken place in Milan: Ambrose would certainly have mentioned them if they had..$^{75}$ Whether or not Auxentius was an "Arian" is beside the point: what is significant is that even here, in what might seem an open-and-shut case, Ambrose goes out of his way to avoid making specific accusations of heresy. ${ }^{76} \mathrm{He}$ is content to conjure up an impression of "Arian" hostility, without ever committing himself to the claim that his opponents are really "Arian" heretics.

All of this may be excused as the mere exercise of tact, since it was no doubt politic to refrain from accusing the emperor and his intimates of heretical views. It may imply a recognition on Ambrose's part that, even if the dispute was indeed doctrinally motivated, the term "Arian" was strictly inapplicable to his opponents: as is clear from the law issued by the imperial court in January 386 , the limits of acceptable doctrinal discourse continued to be set by the more ambiguous provisions of the Council of Rimini. ${ }^{77}$ But the exaggerated care with which Ambrose avoids making doctrinal difference the core of the issue should require us to take similar care in assessing his precise allegations. It is clear enough that the demand has been made for a basilica, for the use of the imperial court at an Easter service; and Ambrose asks to be reassured that the basilica will not as a result be handed over to "Arians" ${ }^{7}{ }^{8}$ This in itself seems to rest on a distinction between the imperial court and the "Arians", which may be supported by Ambrose's reluctance to call even Auxentius an "Arian" directly. But if these "Arians" are quietly associated with the court, they are at no point placed among the Christians of Milan. In his attacks on Auxentius, Ambrose insists that he has no following in Milan itself. ${ }^{79}$ Despite the suggestion of Neil McLynn that Auxentius was preaching widely in Milan, even 'beyond the confines of his own sect', Ambrose never pictures him preaching in public. ${ }^{8 \circ}$ On the contrary, he rests his case on Auxentius's apparent unwillingness to submit to the judgement of the people. ${ }^{81}$ This may be a misrepresentation of the real position: no doubt

75 The arguments of Williams (1995) 209-10 and McLynn (1994) 185, 206 n.160 presume that Auxentius was genuinely engaged in a programme of rebaptisms in Milan; but this gives too much weight to a charge which is clearly about Auxentius's (reputed) views rather than his actions.

76 The true doctrinal positions of Auxentius can be known with more certainty if he is identified with Auxentius of Durostorum, the author of a letter on the life of Ulfila. For this identification see Klein (1953); it is accepted in most modern studies, but note the doubts expressed at Duval (1998) 29-31.

77 CTh 16.1.4.

78 Amb. Ep. 75[21].19: 'utinam liquido mihi pateret quod Arrianis ecclesia minime traderetur!'; cf. Amb. Ep. $75 \mathrm{a}[21 \mathrm{a}] .3$.

79 Amb. Ep. $75[21] .8$ allows him the support of only a few foreigners; cf. 7: 'omitto quia iam ipse populus iudicauit' and Amb. Ep. 75a[21a].34: Ambrose's beliefs are proclaimed 'totius populi ore'.

80 McLynn (1994) 185: the services McLynn says are 'explicitly attested' at Amb. Ep. 75a[21a].25 are not implied by the phrase 'et legerunt et hodie', which merely refers to a supposed "Arian" interpretation of the day's reading, as established by the references in the previous paragraph. Much the same applies to McLynn's other examples: the claim that Auxentius 'preached regularly beyond the narrow confines of his sect' misreads Ambrose's joke at Amb. Ep. 75a[21a].28, which observes that Auxentius cannot have made the case for his beliefs to his judges, since they have not joined him but are still (imagined as) pagans and Jews; and the claim that Auxentius in changing his name appealed to a rival faction of supporters of the previous Auxentius makes little sense, since if they shared his beliefs there would be no need for him to change his name; the purpose can only have been to appeal to those among Ambrose's own flock with fond memories of his predecessor.

81 Amb. Ep. 75a[21a].27-8: 'quis igitur uobis iniuriam facit, qui recusat uestram an qui eligit audientiam?' 
Ambrose had his critics in Milan, and Auxentius might have found supporters among them. Quite possibly Ambrose was bluffing, and if so he was doing so with remarkable confidence. But his stance here cannot constitute positive evidence for substantial doctrinal opposition to him among the Christians of Milan.

With this in mind, we may return to the other ancient sources which relate the events of the basilica crisis. By and large, these are the basis of the traditional interpretation in which the opposition to Ambrose is placed at court; none of them assigns any significant role to a rival doctrinal faction among the Christians of Milan. Augustine, who was present in Milan in 386, refers only to a campaign by Justina; so too does Gaudentius of Brescia, who was a close ally of Ambrose's and knew at least one of the courtiers involved in the crisis. ${ }^{82}$ Rufinus of Aquileia, who was familiar at least with the region, also focuses solely on Justina. ${ }^{83}$ Finally, Paulinus of Milan, who worked closely with Ambrose in the 390s, and had access to his letters and other documents, frames the whole crisis in terms of the campaign against Ambrose by Justina. ${ }^{84}$ Admittedly Paulinus also refers to "Arians" in general terms, but every one of the "Arians" he mentions in the whole of his account of the basilica crisis and its ramifications - as well as in his account of Ambrose's prior relations with the emperor Gratian - is directly associated with the imperial court. ${ }^{85}$ The convergence of our best sources on this one explanation has not gone unnoticed, even among those who insist on the presence of "Arians" among the Christians of Milan. ${ }^{86}$ Certainly it may be regarded with suspicion, whether as an example of the habitual misogyny of ancient sources, or of their fondness for personalised accounts of complex events. ${ }^{87}$ But it is nevertheless clear that this impression of the dispute is consonant with, where not actually derived from, Ambrose's own account. ${ }^{88}$ If we are to reject the primary sources, we must at least take care over what we replace them with.

82 Aug. Conf. IX.7.15; Gaud. Brix. Praef. ad. Beniuolum 5.

83 Ruf. HE XI.15.

84 Paul. Med. V. Amb. 11-18.

85 There is only one exception, who like the priest Castulus is unpromising ground on which to build up a separatist congregation: an anonymous figure presented as an implacable "Arian", but whose miraculous conversion depends on his voluntarily attending the main city basilica to hear Ambrose preach: Paul. Med. V. Amb. 17.

86 Thus Liebeschuetz (2005) 136 observes it as 'an interesting fact' with little further comment; Maier (1994) 84 notes that an analysis of events in terms of a clash between Justina and Ambrose 'rests to a large degree on the primary sources, which vilify Justina as motivated by deceit and the desire to break the power of Ambrose'.

87 Maier (1994) 84: 'it is too superficial to portray the events ... solely as the outcome of a clash of personality'; cf. 84 n. 44: 'Such portrayals are of course to be expected from pro-Nicene authors of the period.'

88 Maier (1994) 84 n. 44: 'Rufinus ... was expanding on the interpretation of Justina's character provided by Ambrose'; see also Cameron (2011) 80-7 on Paulinus's dependence on Ambrose's letters. 


\section{Conclusion}

In the letters and sermons which constitute our primary evidence for the basilica crisis, and in the subsequent narratives which built on them in late antiquity, we find no significant role assigned to a rival doctrinal faction among the Christians of Milan. In his letter to his sister Marcellina, Ambrose names only a single "Arian": Castulus, who by Ambrose's own admission was no more than an innocent bystander. Although in the midst of the crisis he has the soldiers insist on a "catholic" service, this is not directly opposed to an "Arian" one; and indeed he may be taken explicitly to deny the presence of "Arians" among the citizens of Milan. Admittedly Ambrose is eager to hint at the involvement of "Arian" heretics in influencing the court, and it is no surprise that in doing so he should direct his attacks towards Auxentius and not towards the emperor or his mother: to accuse the emperor directly of heresy would have been audacious in the extreme. But even in the extensive assault on Auxentius the links are at one remove: he is attacked for his barbarian origins, his support among only a few foreigners, and for his insistence on fighting his battles at court instead of among the people of Milan. The effect is of course to isolate his opponents so that they seem to be foreign interlopers polluting a pure and untroubled Milanese community. ${ }^{89}$ But this can have worked only up to a point if the true situation was in fact very different, as would have been immediately obvious to his contemporary audience in Milan and to many beyond it. If the "basilica crisis" was indeed merely the latest manifestation of an established rivalry in the city, it is difficult to see who would have been persuaded by Ambrose's efforts to remodel it as an isolated assault by a blow-in bishop and his foreign cronies.

Perhaps Ambrose still chose to misrepresent the situation. Certainly he was by no means a disinterested witness, and he was often more concerned to influence events not least by his representation of them - than to report them accurately. Yet the conventional reading of Ambrose's accounts require that his immediate audience in Milan was prepared to go along with a distorted version of events they were witnessing first-hand; and that this version was likewise picked up and repeated by later sources with their own independent knowledge of the situation. It is certainly not impossible that our sources provide the same distorted image of events, and we are not required to believe what they tell us. We may legitimately prefer to suppose on the basis of evidence from elsewhere - from other episodes during Ambrose's time as bishop, or from parallels with contemporary politics in Constantinople - that the Christians of Milan in this era were indeed divided over doctrine. But it must be recognised that to take this step requires us to leave behind the evidence of Ambrose and to privilege instead our own ideas of how it must have been.

My intention is not to make the case that there were literally no "Arians" in Milan in 385/6. The private beliefs of individual Christians are not my concern, no matter how they might be classified by modern theologians, or even in contemporary polemic. But 
the evidence that Ambrose and other contemporaries provide regarding the basilica crisis must be recognised as offering no solid support for the idea that there existed a coherent, oppositional faction in Milan that might have constituted an "Arian" congregation; nor that the events of the crisis were motivated or carried out by such a faction, or even by the court on their behalf. This is ultimately to make a rather negative case, but my hope is that paying close attention to what Ambrose does and does not claim in this instance will allow it to be examined on its own terms, and not fitted into a preconceived model of how doctrinal politics played out in late antiquity. Neil McLynn once appropriately cautioned against imposing too rigid a model of doctrinal communities on the workings of ancient cities, noting that there was little evidence for the concentration of particular allegiances in particular districts: 'Constantinople was no Belfast.9० Although the parallel is more period-appropriate, we may nevertheless question whether Milan was like Constantinople. Ambrose's account may be disguising a reality we see openly admitted elsewhere. But the evidence offers little positive reason to see the crisis of $385 / 6$ as the product of rival indigenous communities. We may prefer to see such a model behind the rhetoric of the time; but we should be wary of taking it for granted as the natural and inevitable form of any late-antique dispute over doctrine.

\section{Bibliography}

Alexander, D. C. (2008) Augustine's Early Theology of the Church: Emergence and Implications 386-91, New York: Peter Lang.

Barnes, T.D. (2000) 'Ambrose and the Basilicas of Milan in 385 and 386: The Primary Documents and their Implications', Zeitschrift für antikes Christentum 4, 282-99.

- (2002) 'Valentinian, Auxentius and Ambrose', Historia 51, 227-37.

- (2011) 'The Election of Ambrose of Milan', in Leemans, J., Van Nuffelen, P., Keough, S. W.J. and Nicolaye, C. (eds) Episcopal Elections in Late Antiquity. Arbeiten zur Kirchengeschichte 119, Berlin: De Gruyter, 39-59.

Beyenka, M.M. (1954) Saint Ambrose: Letters, Washington, D. C.: Catholic University of America Press.

Bowes, K. M. (2008) Private Worship, Public Values, and Religious Change in Late Antiquity, Cambridge: Cambridge University Press.

Burrus, V. (1995) The Making of a Heretic: Gender, Authority, and the Priscillianist Controversy, Berkeley and Los Angeles: University of California Press.

Cameron, A. (2011) The Last Pagans of Rome, Oxford: Oxford University Press.

Colish, M. L. (2002) 'Why the Portiana? Reflections on the Milanese Basilica Crisis of 386 ', Journal of Early Christian Studies 10, 361-72.

Davidson, I.J. (2002) Ambrose: De Officiis. 2 vols, Oxford: Oxford University Press.

Drinkwater, J. F. (1983) 'The "Pagan Underground", Constantius II's "Secret Service", and the Survival, and the Usurpation of Julian the Apostate', in Deroux, C. (ed.) Studies in Latin Literature and Roman History III. Collection Latomus 180, Brussels: Universa, 348-87. 
Duval, Y.-M. (1998) 'Ambroise et l'arianisme occidental', in Y.-M. Duval, L'Extirpation de l'Arianisme en Italie du Nord et en Occident: Rimini (359-60) et Aquilée (381), Hilaire de Poitiers (d.367/8) et Ambroise de Milan (d. 397), Aldershot: Variorum, XI, 1-39.

Errington, R. M. (1997a) 'Christian Accounts of the Religious Legislation of Theodosius I', Klio 79, 398-443.

- (1997b) 'Church and State in the First Years of Theodosius I', Chiron 27, 21-73.

Gottlieb, G. (1973) Ambrosius von Mailand und Kaiser Gratian. Hypomnemata: Untersuchungen zur Antike und zu ihrem Nachleben 40, Göttingen: Vandenhoeck \& Ruprecht.

Gwynn, D. M. (2007) The Eusebians: The Polemic of Athanasius of Alexandria and the Construction of the 'Arian Controversy', Oxford: Oxford University Press.

- (2010) 'Archaeology and the "Arian Controversy" in the Fourth Century', in Gwynn, D. M. and Bangert, S. (eds) Religious Diversity in Late Antiquity [= Late Antique Archaeology 6 (2008)], Leiden: Brill, 229-64.

Hanson, R. P. C. (1988) The Search for the Christian Doctrine of God: The Arian Controversy 318-381, Edinburgh: T\&T Clark.

Heil, U. (2014) 'The Homoians', in Berndt, G. M. and Steinacher, R. (eds) Arianism: Roman Heresy and Barbarian Creed, Farnham: Ashgate, 85-115.

Homes Dudden, F. (1935) The Life and Times of St Ambrose, Oxford: Clarendon Press.

Kalleres, D. S. (2015) City of Demons: Violence, Ritual, and Christian Power in Late Antiquity, Oakland: University of California Press.

Kaufman, P. I. (1997) 'Diehard Homoians and the Election of Ambrose', Journal of Early Christian Studies 5, 412-40.

Klein, K. K. (1953) 'Ist der Wulfilabiograph Auxentius von Durostorum identisch mit dem Mailändischen Arianer bischof Auxentius Mercurinus?', Beiträge zur Geschichte der deutschen Sprache und Literatur 75, 165-91.

Krautheimer, R. (1983) Three Christian Capitals: Topography and Politics, Berkeley and Los Angeles: University of California Press.

Lafferty, M. K. (2003) 'Translating Faith from Greek to Latin: Romanitas and Christianitas in Late Fourth-Century Rome and Milan', Journal of Early Christian Studies 11, 21-62.

Lancel, S. (2002) Saint Augustine. Tr. A. Nevill, London: SCM Press.

LeBeau, C. (1824-1836) Histoire du Bas-Empire, commençant à Constantin-le-Grand. New edn, 21 vols., Paris: Firmin Didot.

Lenox-Conyngham, A. (1982) 'The Topography of the Basilica Conflict of A. D. 385/6 in Milan', Historia $31,353-63$.

Liebeschuetz, J.H.W. G. (2005) Ambrose of Milan: Political Letters and Speeches. Translated Texts for Historians 43, Liverpool: Liverpool University Press.

Lusuardi Siena, S. and Neri, E. (2013) 'La basilica Portiana e S. Vittore al Corpo: un punto di vista archeologico', Studia Ambrosiana 7, 147-92.

Machiavelli, N. (1588) Disputationum de republica, quas discursus nuncupavit, Libri III : quo modo in rebusp. ad antiquorum Romanorum imitationem actiones omnes bene maleve instituantur. Tr. J. N. Stupanus, Montbéliard: Jacques Foillet.

Maier, H. O. (1994) 'Private Space as the Social Context for Arianism in Ambrose's Milan', Journal of Theological Studies n. s. 45, 72-93.

Marcos, M. (1997) 'Emperatrices, Obispos y Corte Imperial en Epoca Teodosiana: El caso de Justina', in Vescovi e pastori in epoca Teodosiana: In occasione del XVI centenario della consecrazione episcopale di S. Agostino, 396-1996. 2 vols, Rome: Institutum Patristricum Augustinianum, $141-60$.

Markschies, C. (1995) Ambrosius von Mailand und die Trinitätstheologie: Kirchen- und theologiegeschichtliche Studien zu Antiarianismus und Neunizänismus bei Ambrosius und im lateinischen Westen, Tübingen: Mohr Siebeck. 
- (2005) Ambrosius von Mailand: De Fide (ad Gratianum): Über den Glauben [an Gratian]. Fontes Christiani 47, Turnhout: Brepols.

Marone, P. (2007-8) 'The Use of the Term Catholicus in the Donatist Controversy', Poemerium 6, $1-11$.

McLynn, N. B. (1992) 'Christian Controversy and Violence in the Fourth Century', Kodai: Journal of Ancient History 3, 15-44; repr. in N. B. McLynn, Christian Politics and Religious Culture in Late Antiquity (Farnham: Variorum, 2009) II.

- (1994) Ambrose of Milan: Church and Court in a Christian Capital, Berkeley and Los Angeles: University of California Press.

- (1997) 'Diehards: A Response', Journal of Early Christian Studies 5, 446-50.

Meslin, M. (1967) Les ariens d'occident, 335-430. Patristica Sorboniensa 8, Paris: Éditions du Seuils.

Nauroy, G. (1988) 'Le fouet et le miel. Le combat d'Ambroise en 386 contre l'Arianisme milanais', Recherches Augustiniennes 23, 3-86; repr. in G. Nauroy, Ambroise de Milan. Écriture et ésthetique d'une exégèse pastorale. Quatorze études (Bern: Peter Lang, 2003) 33-149.

Paredi, A. (1964) Saint Ambrose: His Life and Times. Tr. Joseph Costelloe, Notre Dame, IN: University of Notre Dame Press.

Perrin, M.-Y. (2010) 'The Limits of the Heresiological Ethos in Late Antiquity', in Gwynn, D. M. and Bangert, S. (eds) Religious Diversity in Late Antiquity [= Late Antiquity Archaeology 6 (2008)], Leiden: Brill, 201-27.

Ramsey, B. (1997) Ambrose, London: Routledge.

Schindler, A. (1986-94) 'Catholicus, -a', in Mayer, C. (ed.) Augustinus-Lexikon I, Basel: Schwab \& Co., $815-20$.

Seeck, O. (1913) Geschichte des Untergangs der antiken Welt, vol. V, Berlin: Siemenroth.

Sizgorich, T. (2009) Violence and Belief in Late Antiquity: Militant Devotion in Christianity and Islam, Philadelphia: University of Pennsylvania Press.

van Haeringen, J. H. (1937) 'De Valentiniano II et Ambrosio: Illustrantur et digerentur res anno 386 gestae', Mnemosyne 3 rd series $5,152-158 ; 28-33 ; 229-240$.

von Campenhausen, H. (1929) Ambrosius von Mailand als Kirchenpolitiker, Berlin/Leipzig: De Gruyter.

Walford, H. (1881) The Letters of St. Ambrose, Bishop of Milan, translated with notes and indices, Oxford: James Parker \& Co.

Whiting, C. M. (2011) Non aliud iure dici debeamus quam Christiani: Heresy and Orthodoxy, Catholicity and Schism in the Late Fourth Century. Ph.D. thesis, University of California, Riverside.

Williams, D. H. (1993) 'Ambrose, Emperors and Homoians in Milan: The First Conflict over a Basilica', in Barnes, M. R. and Williams, D. H. (eds) Arianism After Arius: Essays in the Development of the Fourth Century Trinitarian Conflicts, Edinburgh: T\&T Clark, 127-46.

- (1995) Ambrose of Milan and the End of the Arian-Nicene Conflicts, Oxford: Oxford University Press.

- (1996) 'Another Exception to Later Fourth-Century "Arian" Typologies: the case of Germinius of Sirmium', Journal of Early Christian Studies 4, 335-57.

- (1997) 'Politically Correct in Milan: A reply to "Diehard Homoians and the Election of Ambrose", Journal of Early Christian Studies 5, 441-46.

Williams, M. S. (2017) The Politics of Heresy in Ambrose of Milan: Community and Consensus in Late Antique Christianity. Cambridge: Cambridge University Press.

\section{MICHAEL STUART WILLIAMS}

Department of Ancient Classics, Maynooth University, Maynooth, Co. Kildare, IRELAND, Michael.Williams@nuim.ie 
Reproduced with permission of copyright owner. Further reproduction prohibited without permission. 